UDC 614.449 : $616.891 .7: 57.017$

doi: https://doi.org/10.15407/ubj93.01.068

\title{
MALE AND FEMALE RATS DIFFER IN HOMEOSTATIC SHIFTS DURING PRE-SLAUGHTER FEAR STRESS
}

\author{
S. S. GRABOVSKYI ${ }^{1}$, R. R. PANCHUK ${ }^{2}$, N. R. SKOROKHYD ${ }^{2}$, R. S. STOIKA ${ }^{2}$
}

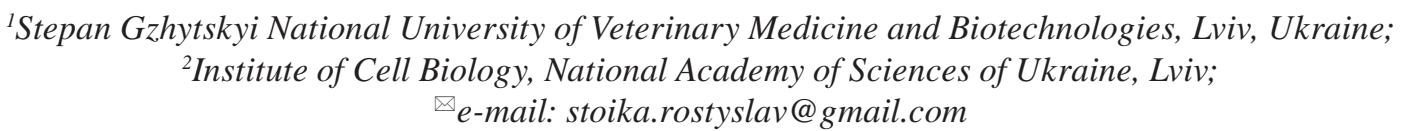

Received: 19 June 2020; Accepted: 17 December 2020

In this investigation, the level of cortisol in blood plasma and splenocytes apoptosis in male and female rats in response to fear stress created by animals' waiting for different terms (20, 40, 60 min) before the slaughter were evaluated. A significant and dependent on the stress state duration increase in the level of cortisol in the blood plasma of both male and female rats compared with the rats of control groups was found, which was more pronounced in females compared to males. The number of Annexin V-positive (apoptotic) cells was determined by FACS analysis. It was shown that the content of apoptotic splenocytes during the stress before slaughter was higher in females compared to males. The prolongation of the stress period was accompanied by an increase in the content of apoptotic splenocytes in males and its decrease in females. The potential hormone-dependent attenuation of the mechanisms of adaptation to stress before slaughter in female rats is discussed.

Ke y words: male and female rats, pre-slaughter fear stress, cortisol, apoptosis.

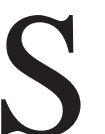

tress is a multi-factorial phenomenon that affects functioning of different organs and systems of the body, including the immune system that is among the most vulnerable to stress. The acute (last minutes) stressors were associated with potentially adaptive up-regulation of the parameters of the innate immunity and down-regulation of some functions of acquired immunity, while the action of chronic stressors was associated with a suppression of both cellular and humoral immune factors. Stress is a process of altered biochemical homeostasis produced by the psychological, physiological, and/or environmental stressors. Any of these stimuli, no matter whether physiological, physical or social, is perceived by the body as challenging, threatening, or demanding one and can be labeled as a stressor. The presence of a defined stressor leads to the activation of the neuro-hormonal regulatory mechanisms that maintain the homeostasis in the body. The overall physiological impact of these factors and the adaptation ability of the body determine the variations in growth, development, productivity, and health status in animals and human [1-3].
Stress decreases the immune responses in different manner. Firstly, it increases the oxidative stress through an increased production of the reactive oxygen species (ROS) [4]. Free radicals interact with other bio-molecules within cells and cause the oxidative damage of plasma membrane, as well as cellular proteins, lipids and DNA [3]. Besides, stress suppresses the antioxidant system, through inhibiting the activity of the enzymes of the antioxidant defense - superoxide dismutase, catalase, glutathione reductase, and glutathione peroxidase [5]. Stress also enhanced apoptosis of specific types of cells through activation of the glucocorticoid receptor (GR) and other mechanisms [6], and the appearance of the apoptotic cells induce the immune response and trigger the immune tolerance [7].

The spleen cells are among the first bio-victims of the stress-induced apoptosis. At physiological conditions, the spleen plays a role of an important peripheral immune organ. The main functions of spleen are: a) destruction of damaged and aged cells; b) an enhancement of the bacterial phagocytosis; c) the accumulation of plasmocytes; d) production

\footnotetext{
(C) 2021 Grabovskyi S. S. et al. This is an open-access article distributed under the terms of the Creative Commons Attribution License, which permits unrestricted use, distribution, and reproduction in any medium, provided the original author and source are credited.
} 
of the immunoglobulins (antibodies). Therefore, a destruction of spleen cells through apoptosis reduces the immune defense of the body provided by the innate and acquired immunity [8]. The physiological functions of spleen are under control of the adrenal and sex hormones. The adrenal hormones inhibit the development and differentiation of B-lymphocytes and their transformation to the plasmatic cells. While the sex hormones (estrogens, prolactin, androgens and others) stimulate differentiation of B-lymphocytes in spleen to their producing of the antibodies [9].

In animals subjected to the oxidative stress, different biological systems are affected by a warning signal from the sympathetic nerves that is transformed through a series of metabolic changes of the glucocorticoids (GCs) $[4,10]$. The GCs are essential endocrine regulators of homeostasis of body functions and adaptation to the environmental changes, e.g. stress. They regulate the essential body functions in mammals, as well as control cell metabolism, growth, differentiation, and apoptosis. Besides, they act as potent suppressors of the inflammation, and multiple immune-modulating mechanisms such as leukocyte apoptosis, differentiation, and cytokine production have been described [11]. There is a link between the GCs and sex hormones because GCs are the primary physiological anti-inflammatory hormones, while the sex hormones may also exert the immune-modulating functions. The sex hormones affect the functions of the immune cells and inflammation. The androgens elicit mainly the antiinflammatory effect, whereas estrogens possess both pro- and anti-inflammatory activity, depending on the type of the immune response or variability of expression of estrogen receptors (ER) and their isoforms [11]. It was suggested that animals' wellbeing is affected by a stress irrespective of their sex [10].

Despite the existing results of experiments on the molecular and cellular mechanisms of stress-induced response [12], these mechanisms stay poorly understood. Of special interest are changes in the organism of animals before a slaughter-induced stress, and sex-dependent differences in such mechanisms are not studied. This interest is caused by the bioethical reasons and the problems of production of high quality meat of the agricultural animals.

The aims of present study were to investigate: 1) the role of stress hormone, cortisol, at the preslaughter fear stress in the laboratory animals (male and female rats); 2) the level of apoptosis in spleno- cytes of male and female rats before the slaughterinduced stress. The reason to perform such experiments was to look for sex-dependent differences in a response of rats to the slaughter fear-induced stress.

\section{Materials and Methods}

White adult Wistar laboratory male and female rats (average mass - 180-220 g) were used in the study. Animals were maintained under standard animal housing conditions in plastic cages with a $12 \mathrm{~h}$ light/dark cycle (light on 7 a.m.) temperature $22^{\circ} \mathrm{C}$ and given standard feed and water. The rats were fed standard briquetted compound feed for laboratory animals (DSTU 4142-2002, manufactured by the LTD D-MIX, Ukraine). Feed intake was monitored daily.

All experiments on animals (laboratory rats) were conducted keeping to the bioethical rules of the European Convention "On protection of vertebrate animals used in experimental and scientific aims" (Strasbourg, 1986), humanity principles of the Directory of the European Community, and the Bio-Ethics Commission of Lviv National University of Veterinary Medicine and Biotechnologies named after Stepan Gzhytskyi (Protocol N2 dated by December 25, 2015).

Four groups of animals (six animals in each group - three male rats and three female rats) were used in the experiments. In the control group (3 males and 3 females), animals were taken gently from the individual cages and slaughtered within 2 min. The rats of three experimental groups Stress 1, Stress 2, and Stress 3 - were taken from each cage from the first to sixth animals ( 3 males and 3 females) simultaneously in $20 \mathrm{~min}, 40 \mathrm{~min}$ and $60 \mathrm{~min}$, respectively. At the end of the experiment, all animals were decapitated under ether anesthesia. The blood was taken at the decapitation point using heparin as anti-coagulant. Spleen was isolated from rat body, put in plastic Petri dish and dissected with scissors. The pincers were used to remove the splenocytes from the spleen, and splenocytes were washed twice with the phosphate buffered saline (PBS) before study.

Cortisol concentration in blood plasma was measured by the ELISA Kit (EIA-1887, DRG International, Inc., USA) using the enzyme-linked immunosorbent assay.

Flow cytometry analysis. Two-color flow cytometry analysis (An+/PI-) was performed for apoptosis measurement. Splenocytes were transferred to 
Annexin-V-binding buffer (100 $\mu$ l per sample), and labeled with $5 \mu 1$ FITC-labeled Annexin V and $2 \mu 1$ Propidium iodide (PI). The tubes were incubated in the dark for $15 \mathrm{~min}$ at room temperature. $300 \mu \mathrm{l}$ of Annexin $\mathrm{V}$ binding buffer was added to each reaction tube to wash the cells. The FACScan flow cytometer (Becton Dickinson, USA) was used for analyses on the first (FL1) and second (FL2) channels. Mode data of 10000 events were collected for each sample, and their analysis was performed using CELL Quest software. The markers for determining positive and negative apoptotic cells were set according to negative controls in all cases to account for background fluorescence.

Statistical analysis. The results were processed statistically with the software package Statistica 6.0 and Microsoft Excel for Windows XP. Probability of difference was assessed by Student's $t$-test. Results were considered statistically significant at $P \leq 0.05$.

\section{Results and Discussion}

The first aim of our study was to compare changes in the level of stress hormone, cortisol, in blood serum of male and female rats before their slaughter depending on the duration of the preslaughter period. We detected (Fig. 1) that the level of this hormone in blood of animals waiting for the slaughter for a longer time (60 min) was higher comparing with such level in animals waiting for the slaughter for a shorter time (20 min) and in control animals (2 min). Such peculiarity was found in both male and female rats, however, the level of cortisol in females was increased to a significantly higher value, comparing to that level in males. There was no difference in the level of this stress hormone in blood serum of male rats waiting in the cages for their slaughter for 20 and $40 \mathrm{~min}$, while there was a $>2.5$ times increase in cortisol level in blood serum of the female rats waiting for their slaughter for the same periods of time. There was 2.2 times increase in the cortisol level in blood serum of male rats waiting for the slaughter $20 \mathrm{~min}(45.4 \mathrm{ng} / \mathrm{ml})$ as compared to animals waiting $60 \mathrm{~min}(98.0 \mathrm{ng} / \mathrm{ml})$, while in the female rats, such increase in the cortisol level was much more significant - 4.5 times (from 27.0 to $121.4 \mathrm{ng} / \mathrm{ml}$ ) (Fig. 1). Thus, one may suggest that female rats are more sensitive to the pre-slaughter fear stress comparing with the male rats.

We did not reveal significant differences between the male and female rats in the content of some indicators of metabolism and the activity of selected enzymes in blood plasma of rats of different sexes (Table). Due to technical problems (big distance between our laboratory and the location of the biochemical analyzer), we could not measure all those indicators in animals of groups under the preslaughter stress.

The second aim of our study was to determine the effect of the pre-slaughter fear stress on the intactness of splenocytes of male and female rats. The amount of the Annexin V-positive (apoptotic) splenocytes was significantly elevated in male rats of Stress 3 (60 min) group and in female rats of all pre-slaughter stress groups $-1,2$ and $3(20,40$ and $60 \mathrm{~min}$ ), compared with the amount of the Annexin $\mathrm{V}$-positive splenocytes in control groups of male and female rats (Fig. 2, 3). It has to be noted that the amount of dying (apoptotic) splenocytes in female rats was considerably higher than in stressed male rats of all experimental groups - Stress 1 (20 min), Stress 2 (40 min) and Stress 3 (60 min). In the male rats of Stress 3 (60 $\mathrm{min}$ ) group, the ratio of dying splenocytes was increased to $23.8 \%$, compared with $14.0 \%$ in Stress $1(20 \mathrm{~min})$ group $(P<0.05)$, while in the female rats, this dynamics was opposite $-31.7 \%$ in Stress 3 (60 min) group, compared with $45.8 \%$ in Stress 1 (20 min) group $(P<0.05)$.

Thus, in the male rats, a positive correlation is observed between the pre-slaughter stress fear-induced increase in the level of cortisol in blood serum and the amount of dying (apoptotic) splenocytes. At the same time, in the female rats, there is a negative

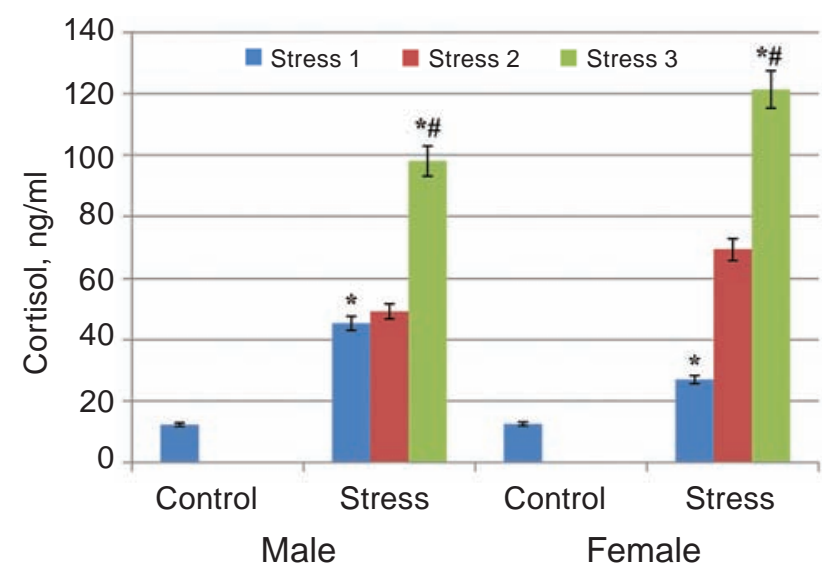

Fig. 1. Cortisol level in blood plasma of male and female rats in different terms before their slaughter. ${ }^{*} P<0.05$ (compared with control); ${ }^{\#} P<0.05$ (female rats of Stress 3 group compared with male rats of Stress 3 group) 
Biochemical indicators in blood plasma of male and female rats $(M \pm m, n=3)$

\begin{tabular}{lcc}
\hline \multicolumn{1}{c|}{ Variable } & Male & Female \\
\hline Albumin, g/l & $28.4 \pm 3.2$ & $27.3 \pm 5.8$ \\
Total protein, g/l & $68.3 \pm 4.2$ & $73.6 \pm 5.2$ \\
Total bilirubin, $\mu \mathrm{mol} / 1$ & $8.6 \pm 3.4$ & $10.2 \pm 2.5$ \\
ALT, $\mu \mathrm{mol} / \mathrm{h} \cdot \mathrm{ml}$ & $114.4 \pm 7.6$ & $116.7 \pm 7.2$ \\
$\mathrm{AST}, \mu \mathrm{mol} / \mathrm{h} \cdot \mathrm{ml}$ & $151.7 \pm 16.2$ & $187.0 \pm 44.9$ \\
$\mathrm{LDH}, \mathrm{U} / \mathrm{l}$ & $668.7 \pm 72.9$ & $449.7 \pm 327.3$ \\
Alk-P, $\mathrm{U} / 1$ & $11.7 \pm 6.5$ & $10.7 \pm 2.6$ \\
Creatinin, $\mu \mathrm{mol} / \mathrm{l}$ & $31.6 \pm 3.0$ & $32.6 \pm 9.6$ \\
Urea nitrogen, $\mathrm{mmol} / 1$ & $8.1 \pm 0.7$ & $7.2 \pm 1.2$ \\
Cholesterol, $\mathrm{mmol} / 1$ & $2.0 \pm 0.1$ & $2.0 \pm 0.2$ \\
Calcium, $\mu \mathrm{mol} / 1$ & $2.7 \pm 0.3$ & $2.8 \pm 0.2$ \\
Phosphorus, $\mathrm{mmol} / 1$ & $1.3 \pm 0.1$ & $1.4 \pm 0.1$ \\
Glucose, $\mathrm{mmol} / 1$ & $9.1 \pm 1.9$ & $9.0 \pm 1.5$ \\
\hline
\end{tabular}

correlation between these parameters - the level of cortisol and the ratio of the apoptotic splenocytes.

The original cytofluorograms of the survival status of splenocytes of male and female rats under pre-slaughter fear stress are presented in Fig. 3.

Thus, for the first time, we revealed that the biological responses of male and female rats to the pre-slaughter fear stress created by different term (20, 40 and $60 \mathrm{~min}$ ) of animal waiting in the stressed conditions before the slaughter are dependent on sex of animals. From three types of measured indicators, two types, namely, the cortisol level in blood plasma of rats and the level of cell death in spleen tissue were more pronounced in the female rats than in the male rats.

The stress is known to trigger the acute and chronic alterations in blood plasma content of the cortisol, and it may result in the alterations of the physiological and behavioral reactions of animals [13-15]. The results of measurement of cortisol level in blood before and after the exposure to the stressor demonstrated an 8-fold elevation of this indicator in the male rats and its 10-fold elevation in the female rats which stayed for $60 \mathrm{~min}$ under the pre-slaughter fear stress, compared with control group (unstressed male and female rats).

At normal metabolism, the ROS participate in several physiological functions like ATP generation, various catabolic and anabolic processes, and cellular redox cycles. However, an excessive generation

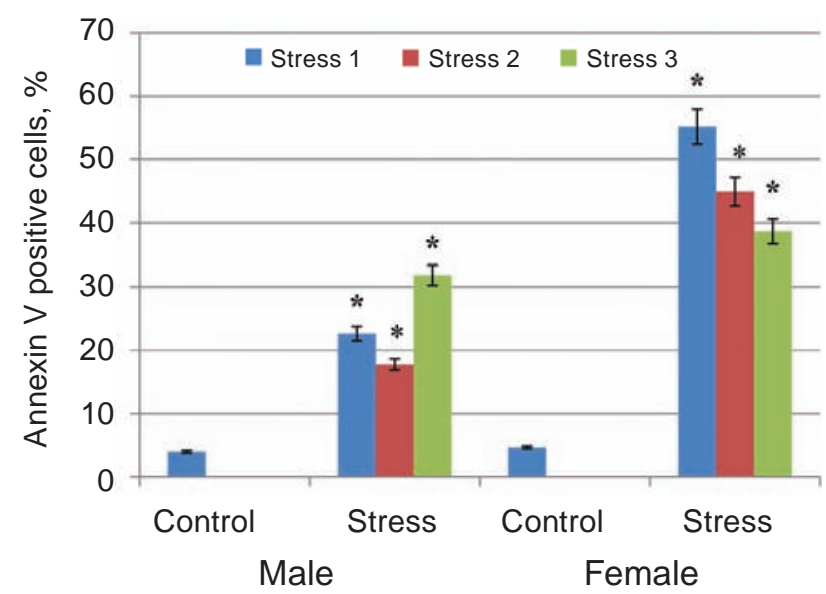

Fig. 2. The ratio (\%) of the Annexin-positive splenocytes in rat male and female during animal fear stress before the slaughter. Dying splenocytes were double stained with Annexin V/Propidium Iodide and estimated by FACS analysis. $* P<0.05$ (compared with control)

of free radicals caused by the endogenous biological or exogenous stressing factors, such as chemical exposure, pollution, or radiation, are harmful (stressful) for the organism [3]. The oxidative stress is triggered by the imbalance between the level of ROS generated as a byproduct of the normal aerobic metabolism and the capacity of the enzymatic and non-enzymatic antioxidant systems to inactivate the ROS excess [12]. Thus, the oxidative damage might be not only a cause, but also a consequence of cell death, including apoptosis and necrosis [12].

Our suggestion is consistent with the increased ratio of the Annexin V-positive (apoptotic) splenocytes detected in both male and female rats under the pre-slaughter fear stress. Other investigators revealed the association between the apoptosis of splenocytes accompanied by the alterations in the expression of mRNA coding for apoptosis regulators (Bax, Bcl-2 and Caspase-3) and the oxidative stress induced by the dietary nickel chloride in broilers [16]. In another study, it was reported that in rats under the experimental hyperthermia stress [7] and in human patients with coronary heart disease [17], both the increased cortisol level and elevated number of the Annexin V-positive (apoptotic) splenocytes take place.

We did not expect to reveal sex-dependent difference in time pattern of dying splenocytes in rats under the pre-slaughter fear stress. A distinctly higher ratio of the apoptotic cells was detected 

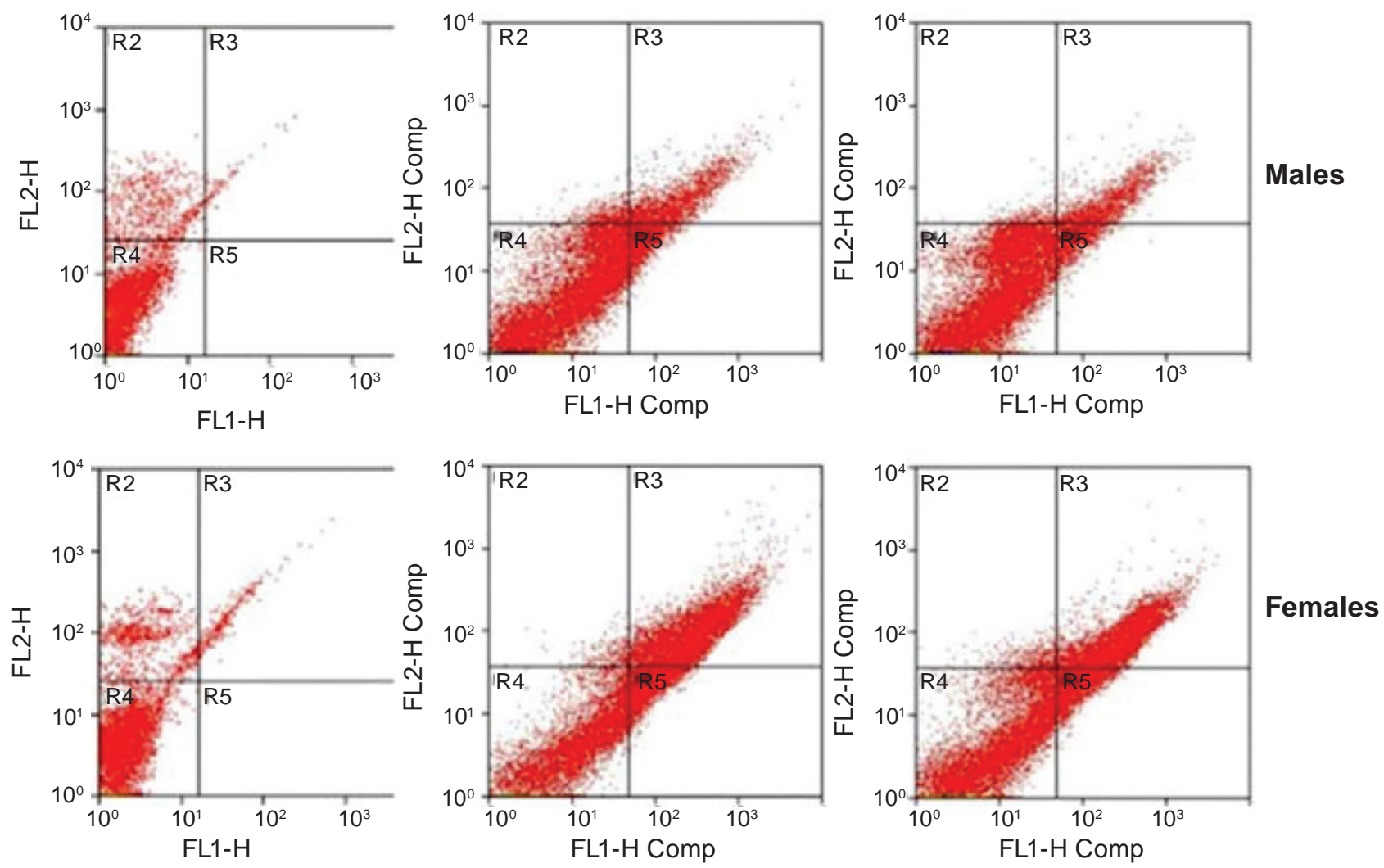

Fig. 3. The cytofluorograms of splenocytes of male and female rats at their stress before the slaughter (R2 necrotic cells; $R 3$ - late apoptotic cells $\left(A n^{+} / P I^{+}\right) ; R 4$ - intact (alive) cells; $R 5-\left(A n^{+} / P I\right)$ early apoptotic cells Fluorescent channels FL1 (Annexin V, x-axis) and FL2 (Propidium iodide, y-axis)

in spleen of the stressed female rats comparing to the stressed male rats. While in female rats, this ratio was decreased with the duration of stress, in male rats, the ratio of the dying splenocytes was increased, although not reaching the ratio value revealed in the female rats under stress. Such difference in the behavior of the immune cells (splenocytes) in the stressed male and female rats might be attributed to the role of sex hormones. The higher prevalence of the apoptotic cells in germinal centers of the female cGVHD mice compared with the male mice implicates a gender-specific factor and suggests that immune activation may be more intense in the females [18]. A balance of the pro- and anti-apoptotic proteins can be changed by the glucocorticoids, and the pro-apoptotic versus anti-apoptotic effect is tissue- and/or cell type-specific [6].

The stress is known to enhance the activity of the hypothalamus-pituitary-adrenal (HPA) axis that results in an increased secretion of the corticosteroids of the adrenal cortex. Cortisol is a biomarker for stress and depressive disorders [18]. Since sex hormones and glucocorticoids (GCs) act in the same cellular pathways regulating leukocytes growth, differentiation, and survival, the simultaneous action of these hormones would likely enhance or abrogate the effects elicited by the individual stressing factors. The corticosteroids and sex hormones are derived from the cholesterol through the same steroidogenic pathway, with common metabolic intermediate, progesterone, and are under the control of the hypothalamus-pituitary-adrenal gland (HPA) axis [11]. A revealed decrease in the amount of the apoptotic splenocytes at simultaneous elevation of the concentration of cortisol in the female rats under the preslaughter fear stress could be explained by blocking the effect of cortisol by the female sex hormones, however, the confirmation of this suggestion needs additional experiments.

Summarizing, we demonstrated that the male and female rats differ in their response to the preslaughter fear stress. The main characteristics of this difference are: 1) higher level of induced cortisol in blood of the stressed female rats, comparing with the stressed male rats; 2) higher amount of the apoptotic cells in spleen of the stressed female rats comparing 
with the stressed male rats; 3 ) opposite pattern of time-dependent change in the amount of the apoptotic splenocytes in the stressed male (increase) and female (decrease) rats. Such changes were induced by the pre-slaughter fear stress and they suggest a suppression of the functions of the immune system that is an important element of homeostasis in the body.

Conclusions. A significant elevation of the cortisol level in blood serum of both male and female rats at the slaughter fear-induced stress was revealed, compared with rats of control (untreated) group. This elevation was more pronounced in the female rats, comparing to male rats. An increase in the cortisol level strongly depends on the duration (20, 40 and $60 \mathrm{~min}$ ) of the pre-slaughter fear stress.

To address a potential immune constituent in the response of pre-slaughter fear-induced stress in rats, a survival status of spleen cells was estimated as a ratio of the Annexin V-positive cells measured by FACS analysis. Sex-dependent difference between time-dependent patterns of changes in the amount of the apoptotic splenocytes was revealed. While in the male rats, an increase in the duration of the pre-slaughter stress led to an increase in number of the dying splenoctes, in the female rats, such prolongation of the pre-slaughter stress led to a decrease in number of the dying splenocytes. It should be noted that the amount of dying splenocytes in the stressed female rats stayed significantly higher than such amount in the stressed male rats.

The results of this study suggest both cortisoldependent regulation and potential sex hormonedependent regulation of the mechanisms of animal adaptation to the pre-slaughter fear stress.

Conflict of interest. Authors have completed the Unified Conflicts of Interest form at http://ukrbiochemjournal.org/wp-content/uploads/2018/12/ coi_disclosure.pdf and declare no conflict of interest.

Funding. The research was carried out within the framework of the research project "Mechanisms of regulation of metabolism at different functional conditions of animal organism". Registration number $0116 \mathrm{U} 004273$.

\section{ВІДМІННОСТІ ГОМЕОСТАТИЧНИХ ЗРУШЕНЬ У САМЦІВ І САМОК ЩУРІВ ПІД ЧАС СТРЕСУ ПЕРЕД ЗАБОЕМ}

\author{
С. С. Грабовський느, Р. Р. Панчук², \\ H. Р. Скорохід⿱丷, Р. С. Стойка
}
${ }^{1}$ Львівський національний університет ветеринарної медицини та біотехнологій імені С. 3. Гжицького, Україна;

${ }^{2}$ Інститут біології клітини НАН України, Львів;

凶e-mail: stoika.rostyslav@gmail.com

У цьому дослідженні оцінювали рівень кортизолу в плазмі крові та апоптоз спленоцитів у самців і самок щурів під час стресу, який створювався очікуванням тварин у напруженому стані протягом різних термінів $(20,40$ і 60 хв) перед забоєм. Виявлено значне залежне від тривалості стресового стану підвищення рівня кортизолу в плазмі крові як самців, так і самок щурів перед забоєм порівняно зі щурами контрольних груп, вираженіше в самок порівняно i3 самцями. Кількість анексин V-позитивних (апоптотичних) клітин визначали за допомогою FACS-аналізу. Вміст апоптотичних спленоцитів у період стресу перед забоєм був вищим у самок порівняно із самцями. Показано, що подовження періоду стресового стану перед забоєм супроводжувалось зростанням вмісту апоптичних спленоцитів у самців та його зменшенням у самок. Обговорено потенційне гормонзалежне ослаблення механізмів адаптації до стресу перед забоєм в самок щурів.

К л ю ч о в і с л о в а: самці та самки щурів, стрес перед забоєм, кортизол, апоптоз.

\section{References}

1. Grabovskyi S, Grabovska O, Havryliak V, Kalachniuk L, Velyka A. Pre-slaughter stress affects cortisol and adrenocorticotropic hormone levels in the blood of animals. Biologija. 2019; 65(3): 174-183.

2. Grabovskyi SS, Kyryliv JI, Grabovska OS. The effect of consumption of broiler chickens meat in conditions of pre-slaughter stress with its correction on natural resistance of people. Acta Sci Pol Zootechnica. 2015; 14(4) 55-64. 
3. Rahal A, Kumar A, Singh V, Yadav B, Tiwari R, Chakraborty S, Dhama K. Oxidative Stress, Prooxidants, and Antioxidants: The Interplay. BioMed Res Int. 2014; 2014: ID761264.

4. Vélez-Marín M, Hurtado Salazar A, UribeVelásquez LF. Plasma cortisol activity in rats under conditions of chronic stress supplemented with resveratrol. Colomb Med (Cali). 2012; 43(3): 221-225.

5. Vaziri ND, Lin CY, Farmand F, Sindhu RK. Superoxide dismutase, catalase, glutathione peroxidase and NADPH oxidase in lead-induced hypertension. Kidney Int. 2003; 63(1): 186-194.

6. Gruver-Yates AL, Cidlowski JA. Tissue-specific actions of glucocorticoids on apoptosis: a doubleedged sword. Cells. 2013; 2(2): 202-223.

7. Wang LI, Liu F, Luo Y, Zhu L, Li G. Effect of acute heat stress on adrenocorticotropic hormone, cortisol, interleukin-2, interleukin-12 and apoptosis gene expression in rats. Biomed Rep. 2015; 3(3): 425-429.

8. Golab J, Jakobisiak M, Lasek W, Stoklosa T. Immunologia (nowe wydanie). Warszawa, Wydawnictwo Naukowe PWN SA, 2017. 497 p.

9. Peeva E, Zouali M. Spotlight on the role of hormonal factors in the emergence of autoreactive B-lymphocytes. Immunol Lett. 2005; 101(2): 123-143.

10. Jameel MK, Joshi AR. Effect of acute stress on serum cortisol level in female wistar rats. Int $J$ Healthc Biomed Res. 2015; 03(04): 109-113.

11. Bereshchenko O, Bruscoli S Riccardi C. Glucocorticoids, Sex Hormones, and Immunity. Front Immunol. 2018; 9: 1332.

12. Tang D, Kang R, Berghe TV, Vandenabeele P, Kroemer G. The molecular machinery of regulated cell death. Cell Res. 2019; 29(5): 347-364.
13. Sancho Cantus D, Santiesteban López N, Cuerda Ballester M, Gómez S, Enriquede la Rubia Ortí J. Stress in Parkinson's disease. Cortisol and amylase biomarkers. Systematic review. Revista Cientifica de la Sociedad de Enfermería Neurológica. 2019; 50: 12-22.

14. Glenk LM, Kothgassner OD, Felnhofer A, Gotovina J, Pranger CL, Jensen AN, Mothes-Luksch N, Goreis A, Palme R, Jensen-Jarolim E. Salivary cortisol responses to acute stress vary between allergic and healthy individuals: the role of plasma oxytocin, emotion regulation strategies, reported stress and anxiety. Stress. 2020; 23(3): 275-283.

15. Griebe M, Ebert A, Nees F, Katic K, Gerber B, Szabo K. Enhanced cortisol secretion in acute transient global amnesia. Psychoneuroendocrinology. 2019; 99: 7279.

16. Huang J, Cui H, Peng X, Fang J, Zuo Z, Deng J, $\mathrm{Wu}$ B. The association between splenocyte apoptosis and alterations of Bax, Bcl-2 and caspase- 3 mRNA expression, and oxidative stress induced by dietary nickel chloride in broilers. Int J Environ Res Public Health. 2013; 10(12): 7310-7326.

17. Chen W, Ni J, Qiao Z, Wu Y, Lu L, Zheng J, Chen R, $\mathrm{Lu}$ X. Comparison of the Clinical Outcomes of Two Physiological Ischemic Training Methods in Patients with Coronary Heart Disease. Open Med (Wars). 2019; 14: 224-233.

18. Gong S, Miao YL, Jiao GZ, Sun MJ, Li H, Lin J, Luo MJ, Tan JH. Dynamics and correlation of serum cortisol and corticosterone under different physiological or stressful conditions in mice. PLoS One. 2015; 10(2): e0117503. 